Article

\title{
Dose-Dependent Phytotoxicity of Pesticides in Simulated Nursery Runoff on Landscape Nursery Plants
}

\author{
Shital Poudyal ${ }^{1}$, R. Thomas Fernandez ${ }^{1}\left(\mathbb{D}\right.$, James Owen ${ }^{2}\left(\mathbb{D}\right.$ and Bert Cregg ${ }^{1,3, *}$ \\ 1 Department of Horticulture, Michigan State University, 1066 Bogue Street, East Lansing, MI 48824, USA; \\ poudyals@msu.edu (S.P.); fernan15@msu.edu (R.T.F.) \\ 2 Hampton Roads Agricultural Research and Extension Center, Virginia Tech University, 1444 Diamond \\ Springs Road Virginia Beach, VA 23455, USA; jim.owen@vt.edu \\ 3 Department of Forestry, Michigan State University, 480 Wilson Road, East Lansing, MI 48824, USA \\ * Correspondence: cregg@msu.edu; Tel.: +1-517-614-4406
}

Received: 4 October 2019; Accepted: 6 November 2019; Published: 9 November 2019

\begin{abstract}
Managers of ornamental nurseries are increasingly reusing runoff water as an irrigation source, but residual pesticides in recycled water may result in plant phytotoxicity on crop plants. Our study focused on understanding the responses of container-grown landscape plants to residual pesticides in irrigation water. Hydrangea paniculata 'Limelight', Cornus obliqua 'Powell garden', and Hosta 'Gold standard' were exposed to various concentrations of isoxaben, chlorpyrifos, and oxyfluorfen $(0,0.15,0.35,0.7$, and $1.4 \mathrm{mg} / \mathrm{L}$ of isoxaben; $0,0.05,0.1,0.2$, and $0.4 \mathrm{mg} / \mathrm{L}$ of chlorpyrifos; and $0,0.005,0.01,0.015$, and $0.02 \mathrm{mg} / \mathrm{L}$ of oxyfluorfen) applied as overhead irrigation. After three months of application, we assessed the dry weight biomass, growth, and parameters related to photosynthetic physiology (SPAD chlorophyll index, light-adapted chlorophyll fluorescence, and photosynthesis carbon dioxide response $(\mathrm{A} / \mathrm{Ci}$ ) curves. We also sampled plant leaf, stem, and root tissues for residual pesticides. The effects of the pesticides were pesticide-specific and taxa-specific. Exposure to oxyfluorfen resulted in visible injury in all three taxa and reduced total biomass, chlorophyll index, and photosynthesis in Hydrangea and Hosta. All three taxa absorbed and retained pesticides in leaf and stem tissues. Growers should follow best management practices to reduce exposure from irrigation with runoff, particularly for herbicides with post-emergent activity.
\end{abstract}

Keywords: nursery runoff; isoxaben; oxyfluorfen; chlorpyrifos; photosynthesis; A/Ci curve

\section{Introduction}

Horticulture is a major industry in the U.S. In 2014, the sale of floriculture, nursery, and specialty crops were worth $\$ 13.8$ billion, up by $18 \%$ since 2009 [1]. For container nurseries, irrigation is often applied based on general rules of thumb, such as $19 \mathrm{~mm}$ of water per day. These application rates often greatly exceed plant water needs and result in substantial runoff [2,3]. In a nursery with $4 \mathrm{~L}$ containers placed six inches apart, up to $80 \%$ of applied water may be lost as runoff [4]. Furthermore, frequent pesticide application is common among nursery producers. Therefore, runoff generated from container nurseries may contain various pesticides, and if released without treatment, surface water contamination and toxicity to aquatic life can occur [5-7]. Due to the significant freshwater use by the nursery industry and the environmental problems associated with runoff, water regulations for nurseries are becoming more stringent. To cope with new regulations and ensure water security, the capture and reuse of runoff water is increasing among nursery growers [8-10]. While capturing and reusing runoff may be a practical solution to reduce contaminants in neighboring ecosystems, growers' concerns about potential negative impacts of residual pesticide on crop growth and quality 
may impede its adoption [10] as nursery growers report evidence of pesticide phytotoxicity when runoff water is used for irrigation (personal communication with growers).

In the current study, we examined the impacts of isoxaben, oxyfluorfen, and chlorpyrifos on three widely cultivated nursery crops. We selected these compounds for study because they are commonly used in the nursery trade and represent different modes of action. Moreover, all three pesticides may be found in nursery runoff, and if present at higher concentrations, can injure nursery plants [11-13]. Isoxaben (common tradenames Gallery ${ }^{\circledR}$, Snapshot ${ }^{\circledR}$ ) is a pre-emergence herbicide that works by inhibiting cell wall biosynthesis in dividing cells, causing stunted plants. Various nursery plants are susceptible to this herbicide. Isoxaben at $5 \mathrm{mg} / \mathrm{L}$ reduced plant height, leaf emergence, and photosynthesis in Canna generalis (canna), Pontaderia cordata (pickerel weed), and Iris (charjoys Jan) [14]. Isoxaben at $10 \mathrm{mg} / \mathrm{L}$ also reduced root visual appearance in Pennisetum rupeli (fountain grass) and Hemerocallis hybrid (daylily) as well as fresh root weight in Ilex crenata ("Helleri" Hellers holly) [11], but isoxaben application at $1.1 \mathrm{~kg}$ a.i./ha alone did not injure six different container-grown ornamental grass species [15], nor did it affect plant height in Ilex crenata (Japanese holly). Chlorpyrifos (common tradenames Dursban ${ }^{\circledR}$, Lorsban ${ }^{\mathrm{TM}}$ ) is an insecticide that may sometimes affect plants by inhibiting the activity of enzymes for growth and development, causing smaller plants [16]. Chlorpyrifos (525 mg/L) induced membrane disintegration through lipid peroxidation and also increased superdimutase (SOD) activity in Vigna radiata [17]. Chlorpyrifos at $30 \mathrm{mg} / \mathrm{L}$ also reduced growth and biomass in Azolla pinnata [18]. Oxyfluorfen (common tradename Goal) is a widely used pre and post-emergence herbicide in container nursery production. It is mostly used for controlling broadleaf weeds and annual grasses [19]. Oxyfluorfen acts by inhibiting the synthesis of protoporphyrinogen oxidase "PPO" enzymes leading to cell membrane disruption [20]. Oxyfluorfen at $1 \mathrm{~g} / \mathrm{ha}$, when applied as a post-emergence herbicide to control weeds in sunflower, produced severe phytotoxicity on sunflower [21]. Oxyfluorfen is not recommended for use in sunflower, but has been found to be safe on eight different container-grown ornamental crops at $0.9 \mathrm{~kg}$ a.i./ha including red-osier dogwood (Cornus sericea), cranberry cotoneaster (Cotoneaster apiculata), European cranberry viburnum (Viburnum opulus 'Notcutt'), border forsythia (Forsythia intermedia 'Spectailis'), English ivy (Redera helix), green luster holly (Ilex crenata 'Green Luster'), Japanese pachysandra (Pachysandra terminalis), and Browni yew (Taxus $x$ media "Brownii") [22]. Application of oxyfluorfen at $0.07 \mathrm{~kg}$ a.i./ha as a foliar spray produced severe phytotoxicity on Euonymus fortunei (Colorata) [23].

Pesticides in runoff water from nurseries are usually diluted with other water sources and therefore occur at relatively low concentrations. However, frequent, often daily, irrigation with nursery runoff creates the potential for chronic low-dose exposure to an array of pesticides that may have phytotoxic effects. Pesticides that cause phytotoxicity usually interfere with physiological and biochemical processes in non-target plants. Many of these effects are related to photosynthetic function, and measuring these responses can indicate the extent of physiological damage caused by pesticides [24-28]. A novel aspect of our approach in the current study was to examine the potential impacts of chronic, low dose application of pesticides on physiological responses of nursery crops. Advances in portable photosynthesis systems have simplified the measurement of key photosynthetic responses such as $\mathrm{A} / \mathrm{Ci}$ curves that can provide insights into photosynthetic reactions that may be early indicators of phytotoxic responses. For example, the maximum carboxylation rate of ribulose-1,5-bisphosphate carboxylase oxygenase (RuBisCO) ( $\mathrm{Vcmax}$ ) may limit photosynthesis at lower (0 to $200 \mathrm{ppm}$ ) intercellular carbon dioxide concentrations, and the rate of electron transfer for ribulose 1,5-bisphosphate (RuBP) regeneration (J) may limit photosynthesis at higher ( $>300 \mathrm{ppm})$ intercellular carbon dioxide concentrations $[27,29,30]$.

A few studies have described the effects of isoxaben, chlorpyrifos, and oxyfluorfen on various plants $[15,16,31-34]$, but the impact of residual (low) concentrations of these compounds on common landscape nursery plants receiving pesticides for an entire growing season has not been documented. Phytotoxicity of isoxaben, oxyfluorfen, and chlorpyrifos may vary depending on the plant taxa irrigated, the concentration of pesticide in water, and the duration of the pesticide application and growers 
particularly lack information on the long-term phytotoxicity caused by these pesticides in runoff water. They are also unaware of the severity of phytotoxicity caused by these pesticides on common landscape nursery plants. Therefore, understanding the impacts of prolonged exposure to low doses of these pesticides may provide insights into the safe use of recycled runoff for irrigation and ultimately encourage the reuse of runoff water among nursery growers. Therefore, the objectives of this study were to evaluate the morphological and physiological effects of various concentrations of isoxaben, chlorpyrifos, and oxyfluorfen on three commonly cultivated container-grown landscape nursery plants, Hydrangea paniculata 'Limelight', Hosta 'Gold Standard', and Cornus obliqua 'Powell Gardens'.

\section{Materials and Methods}

\subsection{Plant Material and Treatments}

This study was conducted in a greenhouse at the Michigan State University Horticulture Teaching and Research Center (HTRC) located in Holt, Michigan, USA. We used Limelight Hydrangea (Hydrangea paniculata 'Limelight'), Red Rover ${ }^{\circledR}$ silky dogwood (Cornus obliqua 'Powell Gardens'), and Gold Standard Hosta (Hosta 'Gold Standard') potted in 12 L black plastic containers for our study. We planted Hydrangea and Cornus plants as liners in spring 2017 in pine bark and peat moss substrate (80:20; volume: volume). Plants of these two taxa were grown outdoors at the HTRC and received standard nursery culture including $19 \mathrm{~mm}$ of daily overhead irrigation and controlled release fertilizer (19:4:8 N: $\mathrm{P}_{2} \mathrm{O}_{5}: \mathrm{K}_{2} \mathrm{O}$ with micronutrients, 5-6 months, Harrell's LLC, Lakeland, FL, USA) applied as a top-dressing. In early December 2017, Hydrangea and Cornus plants, along with bulbs of Hosta plants, were placed in a walk-in cooler at $6{ }^{\circ} \mathrm{C}$ for five weeks to complete their chilling requirements before they were brought into the greenhouse on January 8,2018 . The temperature in the greenhouse was set to $22^{\circ} \mathrm{C}$, and a sodium lamp provided 16-h of photoperiod. Different concentrations of isoxaben, oxyfluorfen, or chlorpyrifos were applied as overhead irrigation mixed in irrigation water. We selected five different concentrations of each pesticide as treatments $(0,0.15,0.35,0.7$, and $1.4 \mathrm{mg} / \mathrm{L}$ of isoxaben; $0,0.05,0.1,0.2$, and $0.4 \mathrm{mg} / \mathrm{L}$ of chlorpyrifos; and 0, 0.005, 0.01, 0.015, and $0.02 \mathrm{mg} / \mathrm{L}$ of oxyfluorfen). Pesticide rates were based on pesticide residues reported in nursery retention ponds $[13,35,36]$ and the solubility of the pesticides in water. A black 100-L covered plastic tank was used as a stock tank for each treatment. A calculated amount of each pesticide was dissolved in $100 \mathrm{~L}$ of water to achieve the desired concentration. A sump pump was used to agitate the pesticide solution and apply the pesticide solution as overhead irrigation on plants. An irrigation distribution test for treatment zones had a distribution uniformity of $89.73 \%$. Pesticide solutions were freshly prepared two to three times a week. Each pesticide treatment consisted of three taxa and six replications per taxa. Treatments began once all the plants had produced a new flush of growth (8 February 2018). We applied pesticide treatments with each irrigation event that varied from once every three days to every day, depending on plant water use. Pesticide treatments continued for three months.

\subsection{Physiological Measurements and Growth}

A portable photosynthesis system (LI-6400 XT, Li-Cor, Inc., Lincoln, NE, USA) mounted with a leaf chamber fluorometer (LI-6400-40, Li-Cor, Inc., Lincoln, NE, USA) was used to develop A/Ci curves and measure light-adapted fluorescence for all three taxa. A section of a fully mature leaf on either the third or fourth node from the top for Cornus and Hydrangea and on the first or second node for Hosta was used for all physiological measurements. Photosynthetically active radiation (PAR) in the chamber was set to $1500 \mu \mathrm{mol} \mathrm{m} \mathrm{m}^{-2} \mathrm{~s}^{-1}$. The block temperature was set to $25^{\circ} \mathrm{C}$, and the reference $\mathrm{CO}_{2}$, supplied by a $12 \mathrm{~g} \mathrm{CO}_{2}$ cartridge (LI-6400 XT, Li-Cor, Inc., Lincoln, NE, USA), was varied, starting at $0 \mathrm{ppm}$ to $800 \mathrm{ppm}(0,50,100,200,300,400,500,600$, and $800 \mathrm{ppm})$. Net photosynthesis (A) values at various intercellular carbon dioxide concentrations (Ci) were used to generate carbon dioxide response $(\mathrm{A} / \mathrm{Ci}$ ) curves. Data from the $\mathrm{A} / \mathrm{Ci}$ curves were used to estimate $\mathrm{Vcmax}$ and J values using the non-linear equation provided by Sharkey [30]. For light-adapted chlorophyll fluorescence 
measurements, a section of a fully mature leaf of each plant was enclosed in the LI-6400-40 chamber with $1500 \mu \mathrm{mol} \mathrm{m}{ }^{-2} \mathrm{~s}^{-1}$ of PAR, $400 \mathrm{ppm}$ of $\mathrm{CO}_{2}$, and $40-60 \%$ humidity at $25^{\circ} \mathrm{C}$. We acclimatized the leaf for $5 \mathrm{~min}$, after which we measured light-adapted fluorescence (LI-6400xt Instruction Manual, version 6, Li-Cor Inc., Lincoln, NE, USA) to determine the efficiency of photosystem II. SPAD leaf chlorophyll index was also measured on three fully expanded leaves per plant on either the second or third node for Hydrangea and Cornus by using a portable SPAD meter (SPAD-502; Minolta Corporation, Ltd., Osaka, Japan). The variegated golden leaf color of Hosta produced unrealistic values of the SPAD index; hence, we did not measure the SPAD index for those plants.

We examined the leaves of each plant and scored them for visible pesticide injury based on a rating system on a scale of one to ten, with ten being a healthy leaf without damage, and one being a dead leaf. After scoring plants for visible symptoms, the leaves, stems, and roots were harvested, dried in an oven $\left(45^{\circ} \mathrm{C}\right)$, and weighed. All of the dry weights were combined to determine the total dry biomass (TBD). Samples of dried leaves, stem, and roots were sent to a commercial laboratory (Brookside Labs, Laboratories, Inc., New Bremen, OH, USA) to determine the residual levels of isoxaben, chlorpyrifos, and oxyfluorfen in the tissue. The QuEChERS technique was used to extract all tissue samples. Oxyfluorfen and chlorpyrifos were quantified using gas chromatography-mass spectrometry (GC-MS), and isoxaben was quantified using liquid chromatography-tandem mass spectrometry (LC-MS/MS) [37].

\subsection{Statistical Analysis}

All statistical analyses were carried out using SAS (version 9.4; SAS Institute, Inc., Cary, NC, USA). Regression analysis in SAS was carried out for the chlorophyll index and light-adapted fluorescence $\left(\mathrm{Fv}^{\prime} / \mathrm{Fm}^{\prime}\right)$ in response to pesticide treatments. For the total dry biomass (TDB), visual leaf injury, and residual pesticide concentration in the leaves, stems, and roots, we analyzed data using one way ANOVA for each species and pesticide. Vcmax and J estimates derived from A/Ci curves were also analyzed by using one way ANOVA for each taxon and each pesticide treatment. Any data that did not meet the assumption of homogeneity of variance were transformed prior to statistical analysis.

\section{Results}

\subsection{Leaf Visual Injury and Growth in Response to Pesticide Treatment}

Leaf visual injury on plants was observed only for oxyfluorfen applications (Figure 1). Exposure to isoxaben or chlorpyrifos did not result in any visible damage to the taxa tested (data not shown). For oxyfluorfen, 0 and $0.005 \mathrm{mg} / \mathrm{L}$ did not produce any visual symptoms on any taxa. Increasing the oxyfluorfen dose to $0.01 \mathrm{mg} / \mathrm{L}$ produced leaf injury on Hydrangea and Hosta, but not on Cornus. Leaf injury was visible on Cornus plants only at the maximum dose $(0.02 \mathrm{mg} / \mathrm{L})$ of oxyfluorfen application. Visible leaf injury on Hydrangea and Hosta increased with an increasing dose of oxyfluorfen (Figure 1). Visible symptoms of oxyfluorfen exposure included leaf browning and smaller leaves (Figure 2). Oxyfluorfen application also reduced TDB for Hydrangea, but not for Hosta and Cornus (Table 1). For Hydrangea, increasing oxyfluorfen to $0.015 \mathrm{mg} / \mathrm{L}$ did not reduce the TDB, but further increase in dose reduced TDB. For Hosta, the decrease in the TBD was linear but was not statistically significant (Table 1). Exposure to isoxaben or chlorpyrifos in irrigation water did not affect the TDB of any of the taxa tested, except for Hosta, where the application of isoxaben first reduced TDB (till $0.7 \mathrm{mg} / \mathrm{L})$ and then the biomass increased $(1.4 \mathrm{mg} / \mathrm{L})$. 


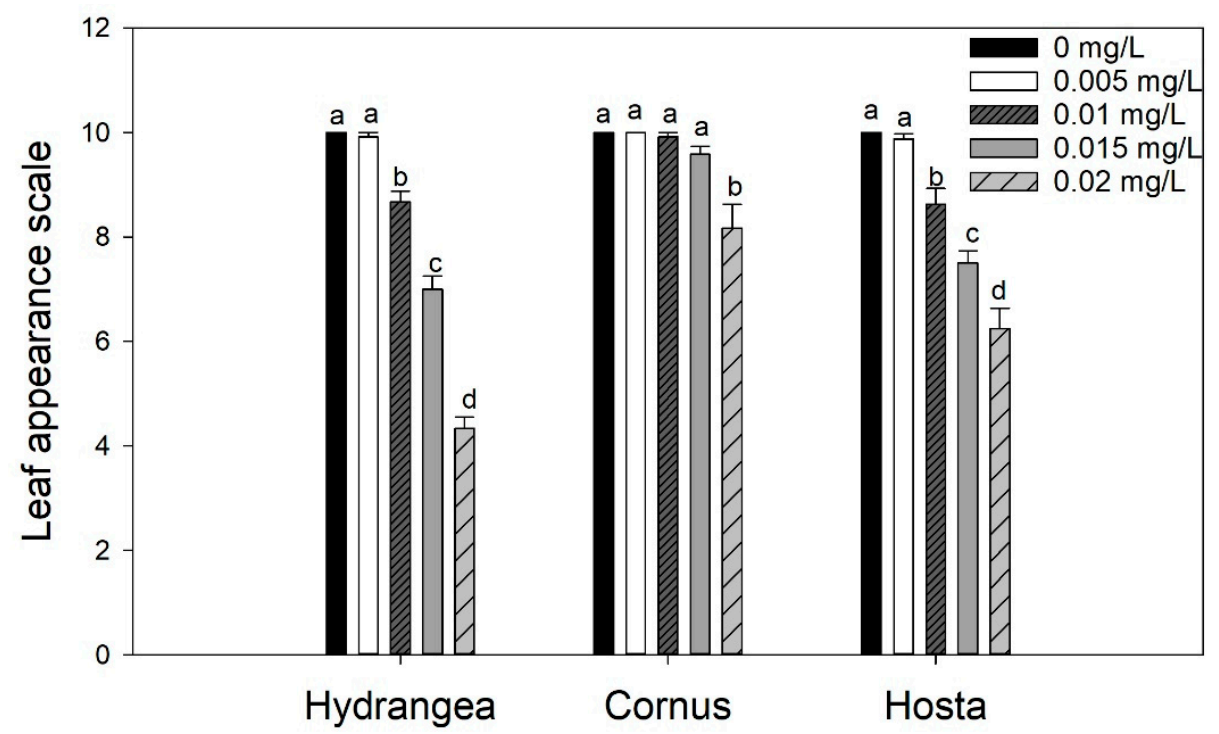

Figure 1. Mean leaf visual rating of Hydrangea paniculata 'Limelight', Cornus obliqua 'Powell Gardens', and Hosta 'Gold Standard' plants irrigated with simulated runoff containing five concentrations of oxyfluorfen for three months. Visual rating was based on a scale of 1 to $10(10=$ no injury to $1=$ dead plant). Means within a taxon followed by the same letter are not different at $p<0.05$. Mean separation was by the Fisher least significance difference (LSD) test.

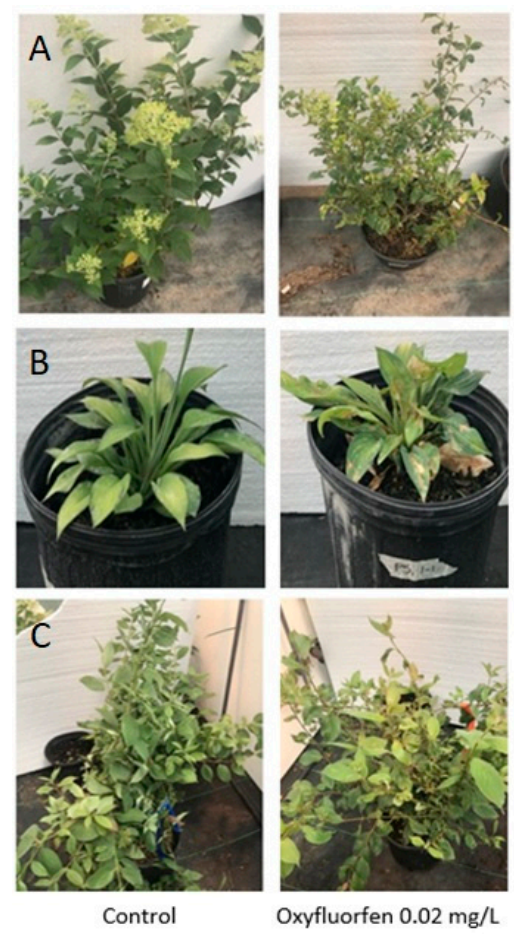

Figure 2. Images of Hydrangea paniculata 'Limelight' (A), Hosta 'Gold Standard' (B) and Cornus obliqua 'Powell gardens' (C) exposed to 0 (control) or $0.02 \mathrm{mg} / \mathrm{L}$ of oxyfluorfen application irrigated for three months. 
Table 1. Mean total dry biomass (g) for Hydrangea paniculata 'Limelight', Cornus obliqua 'Powell Gardens', and Hosta 'Gold standard' plants irrigated for three months with simulated runoff containing oxyfluorfen, isoxaben, or chlorpyrifos. Means within a column followed by the same letter for a given taxon are not different at $\mathrm{p}<0.05$. Post-hoc mean separation was done using the Fisher least significance difference (LSD) test.

\begin{tabular}{|c|c|c|c|}
\hline \multirow{2}{*}{ Concentration (mg/L) } & \multicolumn{3}{|c|}{ Oxyfluorfen } \\
\hline & Hydrangea & Cornus & Hosta \\
\hline 0 & $135.71 \mathrm{ab}$ & $189.65 a$ & $31.58 \mathrm{a}$ \\
\hline 0.005 & $152.97 a$ & $180.68 a$ & $30.23 a$ \\
\hline 0.01 & $153.11 a$ & $188.44 a$ & $23.63 a$ \\
\hline 0.015 & $130.65 a b$ & $210.92 a$ & $22.72 a$ \\
\hline 0.02 & $106.49 b$ & $207.20 a$ & $17.93 a$ \\
\hline \multirow{2}{*}{ Concentration (mg/L) } & \multicolumn{3}{|c|}{ Chlorpyrifos } \\
\hline & Hydrangea & Cornus & Hosta \\
\hline 0 & $135.71 a$ & $189.65 a$ & $31.58 \mathrm{a}$ \\
\hline 0.05 & $139.71 \mathrm{a}$ & $166.40 a$ & $29.76 a$ \\
\hline 0.1 & $138.25 a$ & $213.63 a$ & $41.32 \mathrm{a}$ \\
\hline 0.2 & $138.62 a$ & $197.22 \mathrm{a}$ & $32.38 \mathrm{a}$ \\
\hline 0.4 & $143.45 a$ & $194.87 a$ & $23.71 \mathrm{a}$ \\
\hline \multirow{2}{*}{ Concentration (mg/L) } & \multicolumn{3}{|c|}{ Isoxaben } \\
\hline & Hydrangea & Cornus & Hosta \\
\hline 0 & $135.71 \mathrm{a}$ & $189.65 a$ & $31.58 \mathrm{a}$ \\
\hline 0.15 & $140.63 a$ & $225.85 a$ & $19.11 b c$ \\
\hline 0.35 & $155.07 a$ & $198.92 a$ & $16.54 \mathrm{c}$ \\
\hline 0.7 & $161.66 a$ & $211.75 a$ & $13.05 c$ \\
\hline 1.4 & $141.34 a$ & $186.94 a$ & $27.20 \mathrm{ab}$ \\
\hline
\end{tabular}

\subsection{Physiological Performance in Response to Pesticide Treatments}

Irrigating Hydrangea and Cornus plants with simulated runoff containing oxyfluorfen reduced the SPAD chlorophyll index of leaves. For Cornus, the SPAD chlorophyll index decreased linearly with increasing oxyfluorfen concentration, while the SPAD index for Hydrangea decreased rapidly at oxyfluorfen concentrations above $0.01 \mathrm{mg} / \mathrm{L}$ (Figure 3). Isoxaben and chlorpyrifos did not affect the SPAD index in any of the three taxa (data not shown). Chlorpyrifos and oxyfluorfen did not affect the light-adapted fluorescence in any of the taxa (data not shown). Isoxaben reduced light-adapted fluorescence for Hydrangea and Cornus, but did not affect the Fv'/Fm' of Hosta (Figure 4). In both Hydrangea and Cornus, $\mathrm{Fv}^{\prime} / \mathrm{Fm}^{\prime}$ decreased with increasing isoxaben concentration until $0.07 \mathrm{mg} / \mathrm{L} . \mathrm{Fv}^{\prime} / \mathrm{Fm}^{\prime}$ then remained constant, with further increases in isoxaben concentration (Figure 4). Irrigating with simulated runoff containing oxyfluorfen affected the photosynthetic rates of Hosta and Hydrangea (Figure 5). Exposure to oxyfluorfen reduced photosynthesis rates in Hosta when oxyfluorfen concentration in irrigation water was $0.01 \mathrm{mg} / \mathrm{L}$ or higher. For Hydrangea, exposure to oxyfluorfen decreased photosynthetic rates only when oxyfluorfen concentrations in irrigation were $0.015 \mathrm{mg} / \mathrm{L}$ or more. Exposure to oxyfluorfen in irrigation water did not affect photosynthesis in Cornus. Irrigation with water containing isoxaben slightly reduced photosynthesis for Hosta at concentrations of $0.07 \mathrm{mg} / \mathrm{L}$ or above (Figure 6). Isoxaben did not reduce photosynthesis in Hydrangea and Cornus (Figure 6). Chlorpyrifos did not affect the photosynthesis of any of the taxa tested (data not shown). Reduction in Vcmax and J were only seen for oxyfluorfen application (Figure 7). Oxyfluorfen limited 
photosynthesis in Hydrangea by reducing Vcmax and J at concentrations of $0.015 \mathrm{mg} / \mathrm{L}$ or above, and in Hosta by reducing Vcmax and $\mathrm{J}$ at a concentration of $0.01 \mathrm{mg} / \mathrm{L}$ or above (Figure 7).

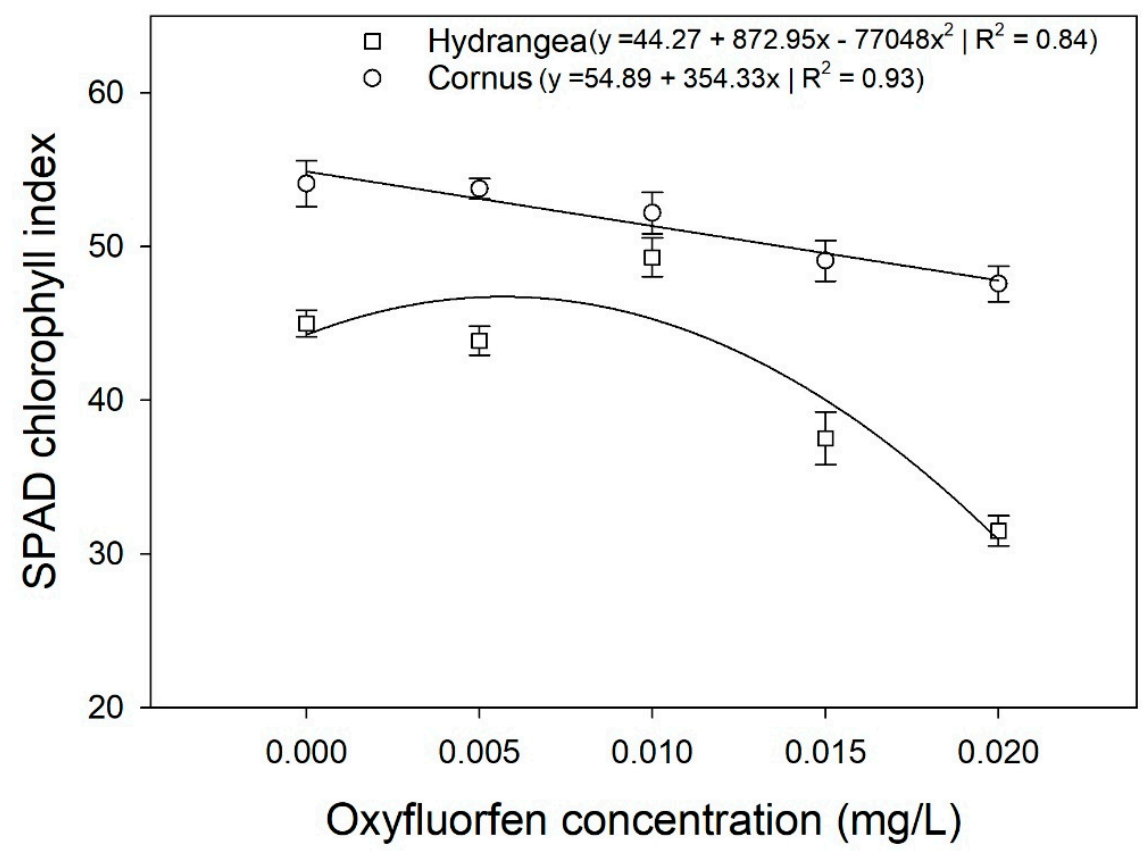

Figure 3. Mean chlorophyll index (CI) of Hydrangea paniculata 'Limelight' and Cornus obliqua 'Powell Gardens' in response to simulated runoff containing five different concentrations of oxyfluorfen applied for three months. CI for Hydrangea followed quadratic regression while the CI of Cornus decreased linearly.

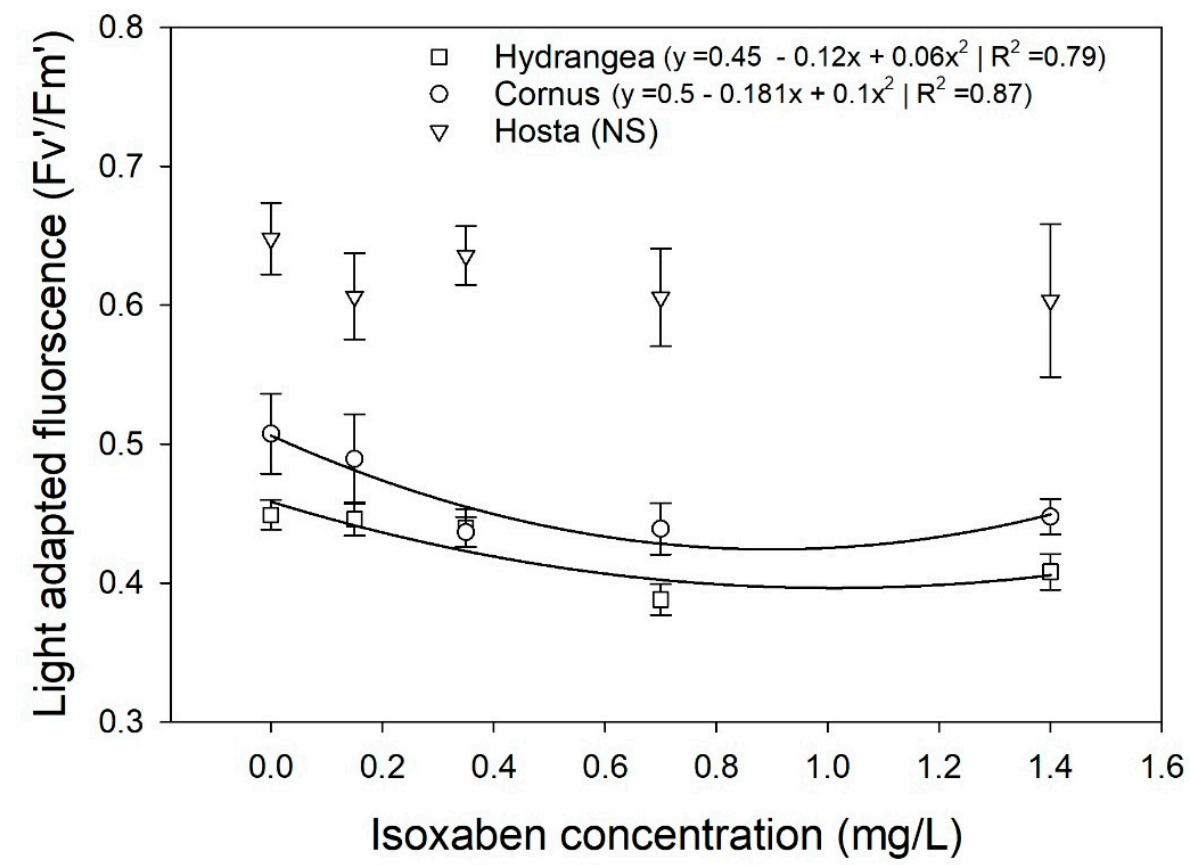

Figure 4. Mean light-adapted fluorescence ( $\left.\mathrm{Fv}^{\prime} / \mathrm{Fm}^{\prime}\right)$ of Hydrangea paniculata 'Limelight', Cornus obliqua 'Powell Gardens', and Hosta 'Gold Standard' plants in response to simulated runoff containing five different concentrations of isoxaben applied for three months. Fv'/Fm' for Hydrangea and Cornus both followed quadratic regression, while regression of Hosta was not significant at $\mathrm{p}<0.05$. 


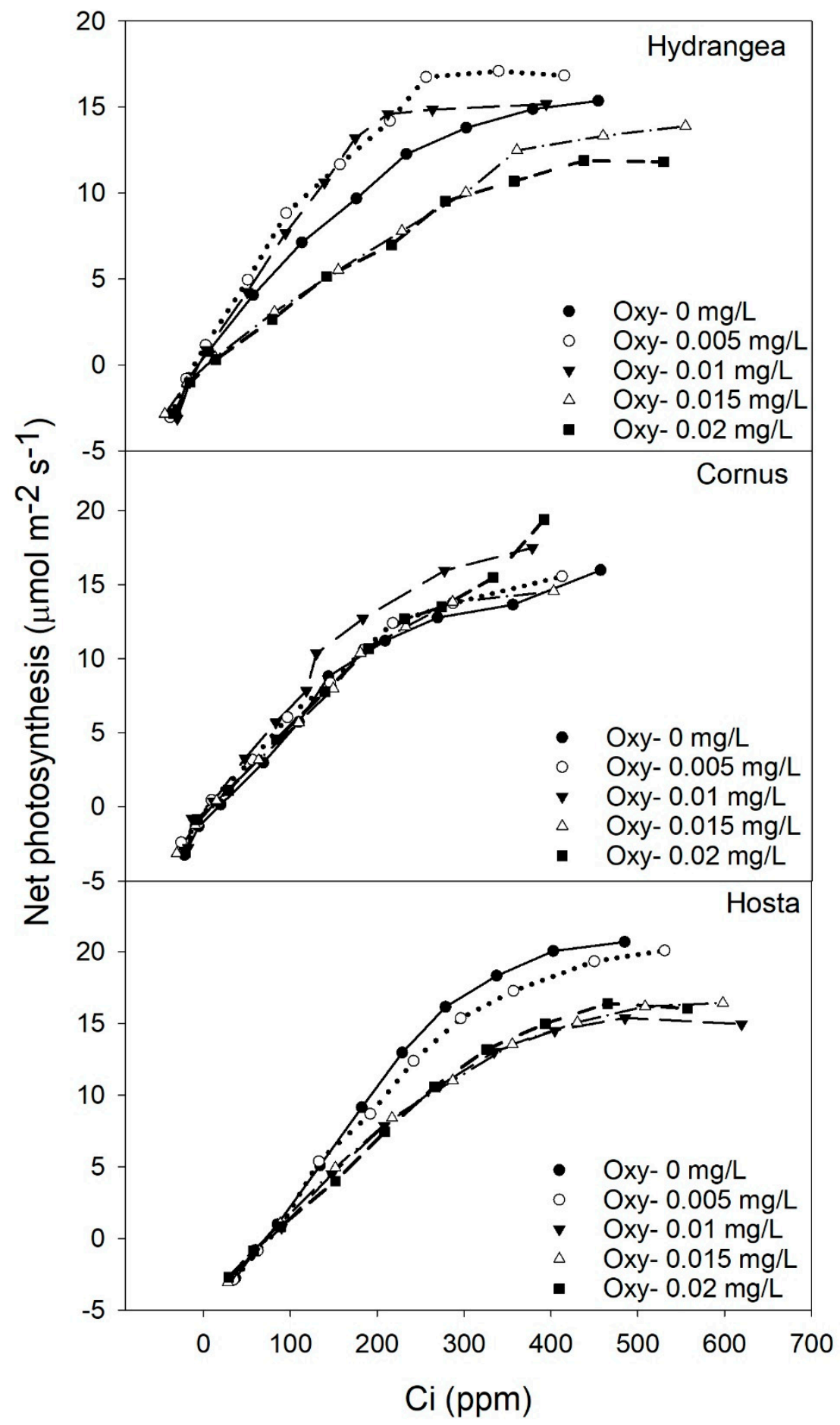

Figure 5. Carbon dioxide response (A/Ci) curve of Hydrangea paniculata 'Limelight', Cornus obliqua 'Powell Gardens', and Hosta 'Gold Standard' plants exposed to five different concentrations of oxyfluorfen (Oxy) for three months. 


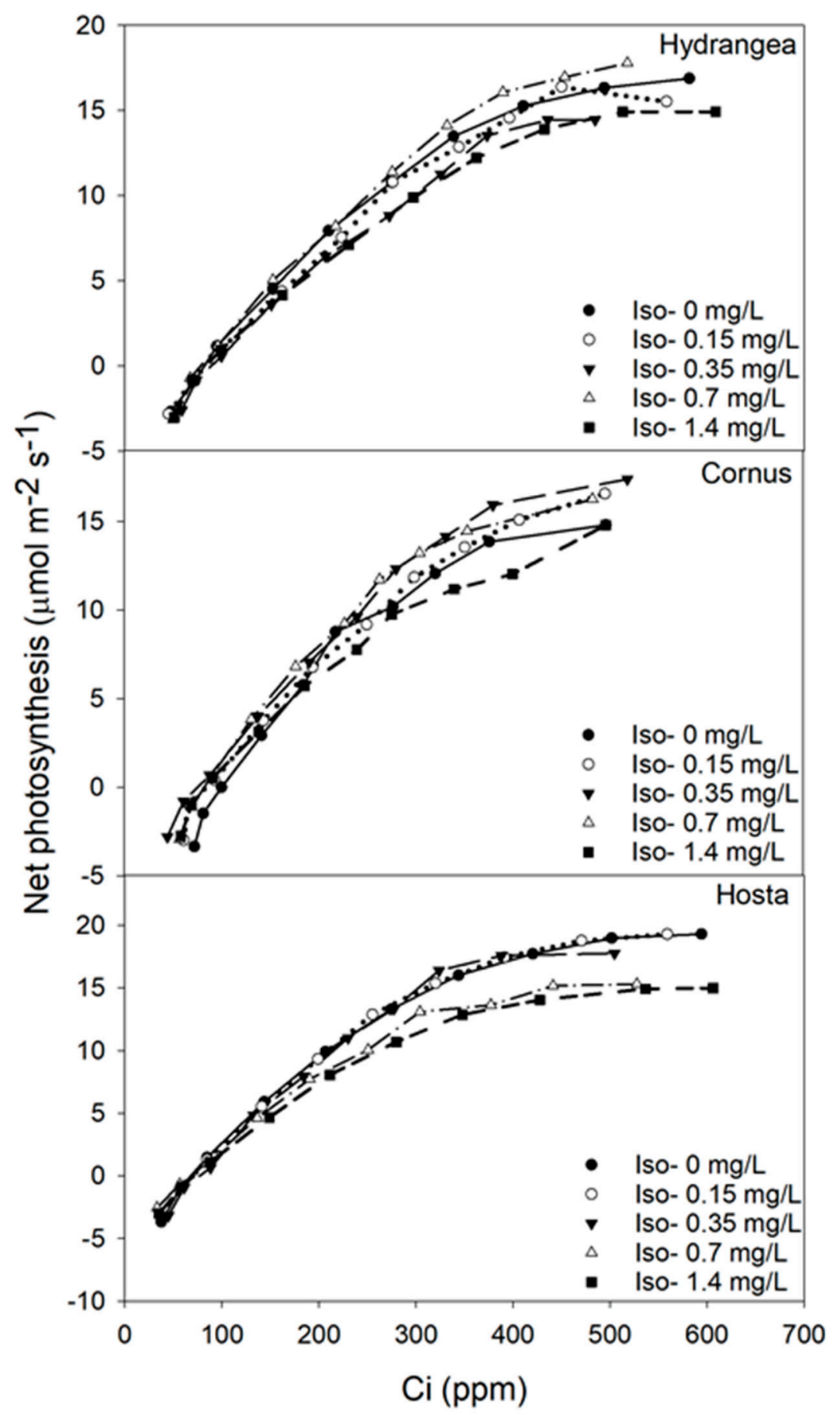

Figure 6. Carbon dioxide response (A/Ci) curve of Hydrangea paniculata 'Limelight', Cornus obliqua 'Powell Gardens', and Hosta 'Gold Standard' plants exposed to five different concentrations of isoxaben (Iso) for three months. 


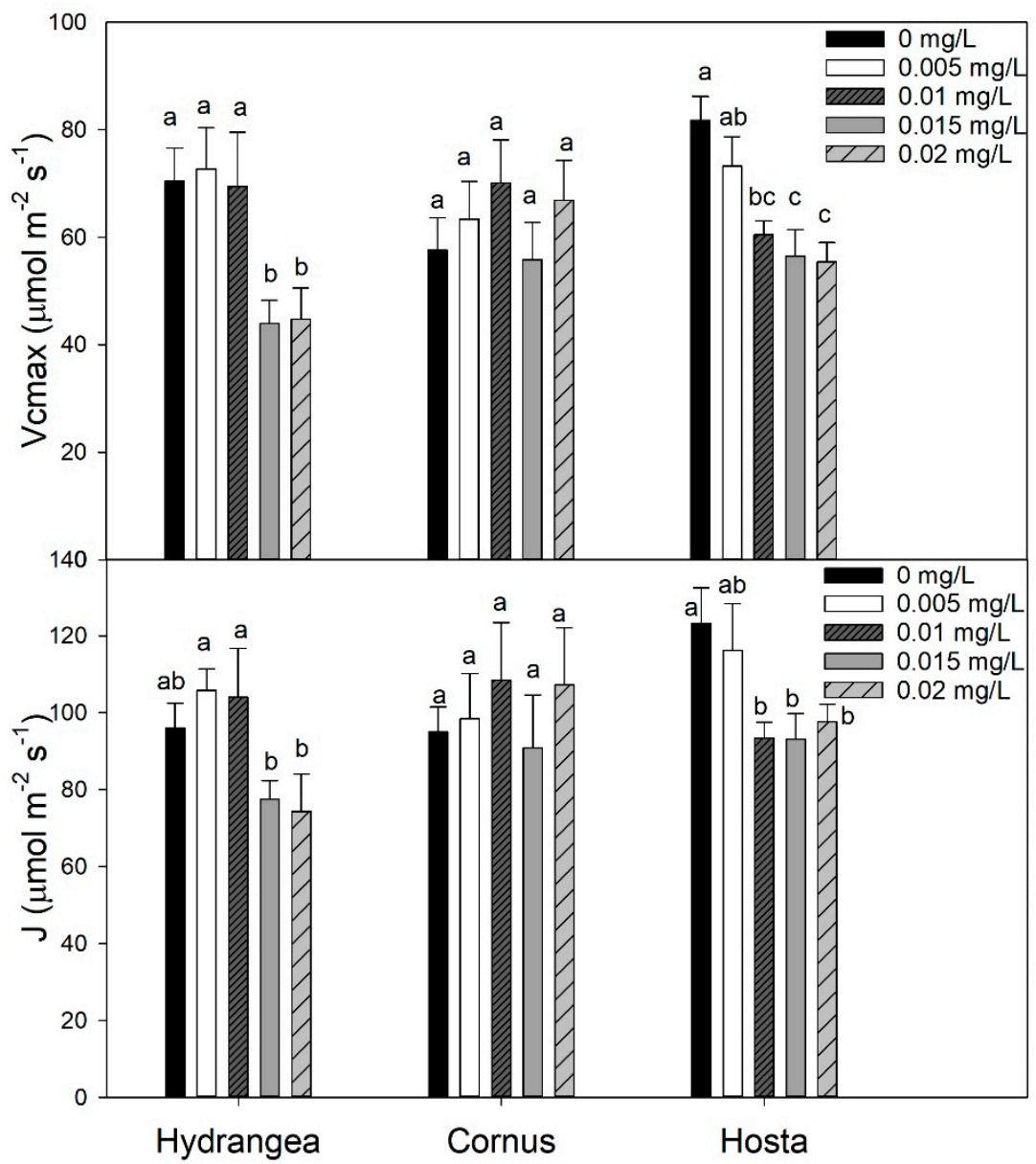

Figure 7. Mean Vcmax (maximum rate of RUBISCO for carboxylation) and J (rate of electron transport for RuBP regeneration) of Hydrangea paniculata 'Limelight', Cornus obliqua 'Powell Gardens', and Hosta 'Gold Standard' plants irrigated with simulated runoff containing five concentrations of oxyfluorfen for three months. Means within a taxon followed by the same letter are not different at $\mathrm{p}<0.05$. Mean separation was by the Fisher least significance difference (LSD) test.

\subsection{Pesticide Absorption}

Leaf pesticide concentration for the pesticides increased with increasing dose (Figure 8). However, taxa varied in their uptake and retention of each pesticide. For oxyfluorfen, Hydrangea had maximum absorption and retention in leaves, followed by Hosta, and then Cornus (Figure 8a). However, for isoxaben and chlorpyrifos, Cornus absorbed the highest amount, followed by Hydrangea and then by Hosta (Figure 8b,c). Isoxaben absorption and retention in leaves were consistently lower in all three taxa when compared to oxyfluorfen and chlorpyrifos. Stem and roots also absorbed and retained pesticides (Figure 9a-f). For all three pesticides, pesticide residues were always present in the stem (Figure $9 \mathrm{a}-\mathrm{c}$ ). The order of pesticide residue concentration in stem was chlorpyrifos $>$ oxyfluorfen $>$ isoxaben. Hosta plants do not have a true stem, therefore, we did not conduct a stem pesticide analysis in Hosta. Fine roots of Hydrangea absorbed and retained oxyfluorfen and isoxaben, but not chlorpyrifos (Figure $9 \mathrm{~d}-\mathrm{f}$ ). For Hydrangea, absorption of oxyfluorfen was greater when compared to isoxaben. Hosta absorbed and retained all three pesticides, but unlike Hydrangea, its pesticide root retention order was chlorpyrifos $>$ isoxaben $>$ oxyfluorfen (Figure $9 d-f$ ). For Cornus, oxyfluorfen was not retained in fine roots, but fine roots absorbed and retained chlorpyrifos and oxyfluorfen (Figure 9d-f). 

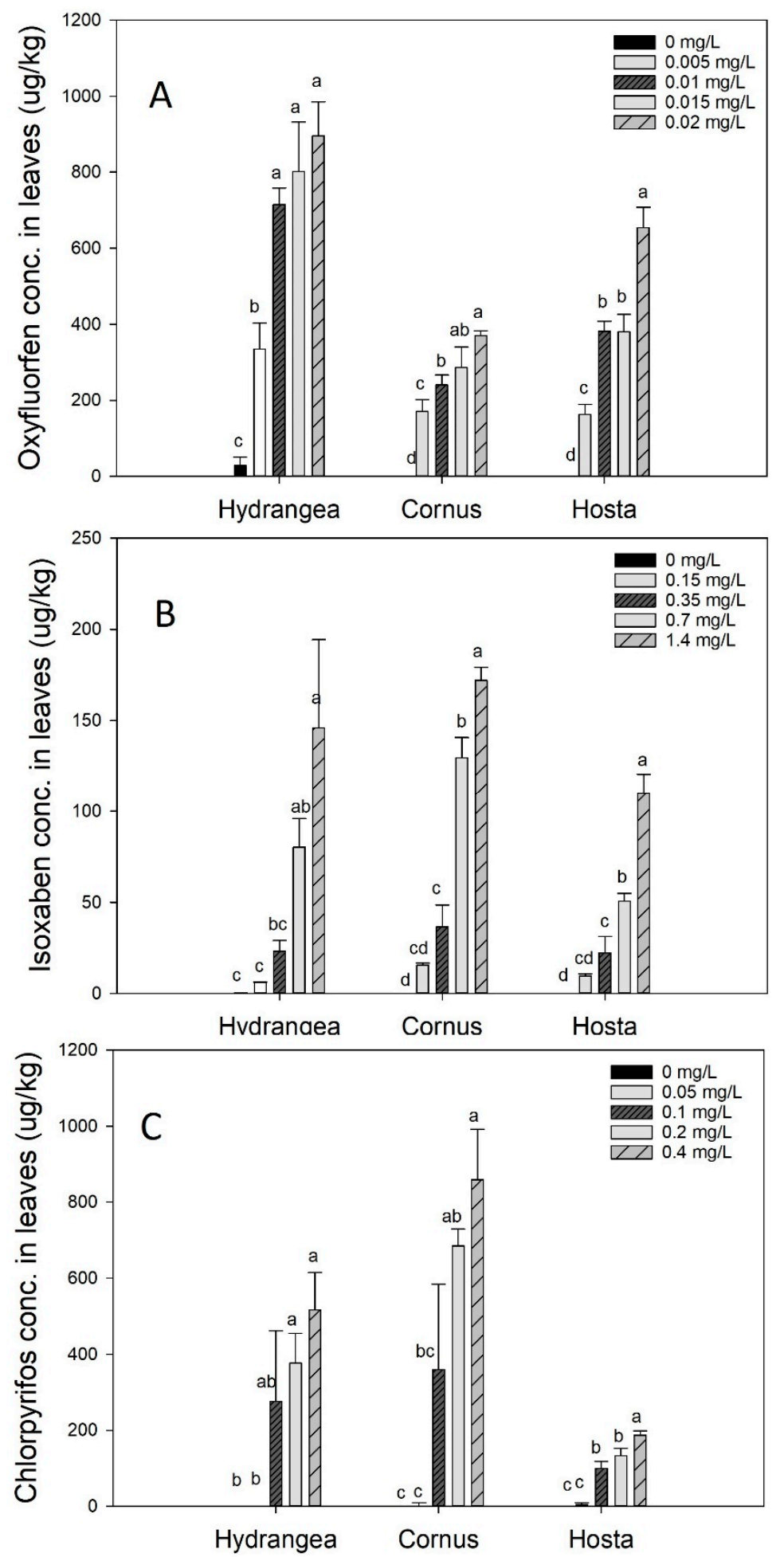

Figure 8. Concentration of oxyfluorfen (A), isoxaben (B), and chlorpyrifos (C) in leaves for Hydrangea paniculata 'Limelight', Cornus obliqua 'Powell Gardens', and Hosta 'Gold Standard' plants following irrigation with simulated runoff containing five different concentrations of oxyfluorfen, isoxaben, and chlorpyrifos applied for three months. Means within a taxon followed by the same letter are not different at $\mathrm{p}<0.05$. Post-hoc mean separation was done using the Fisher least significance difference (LSD) test. 

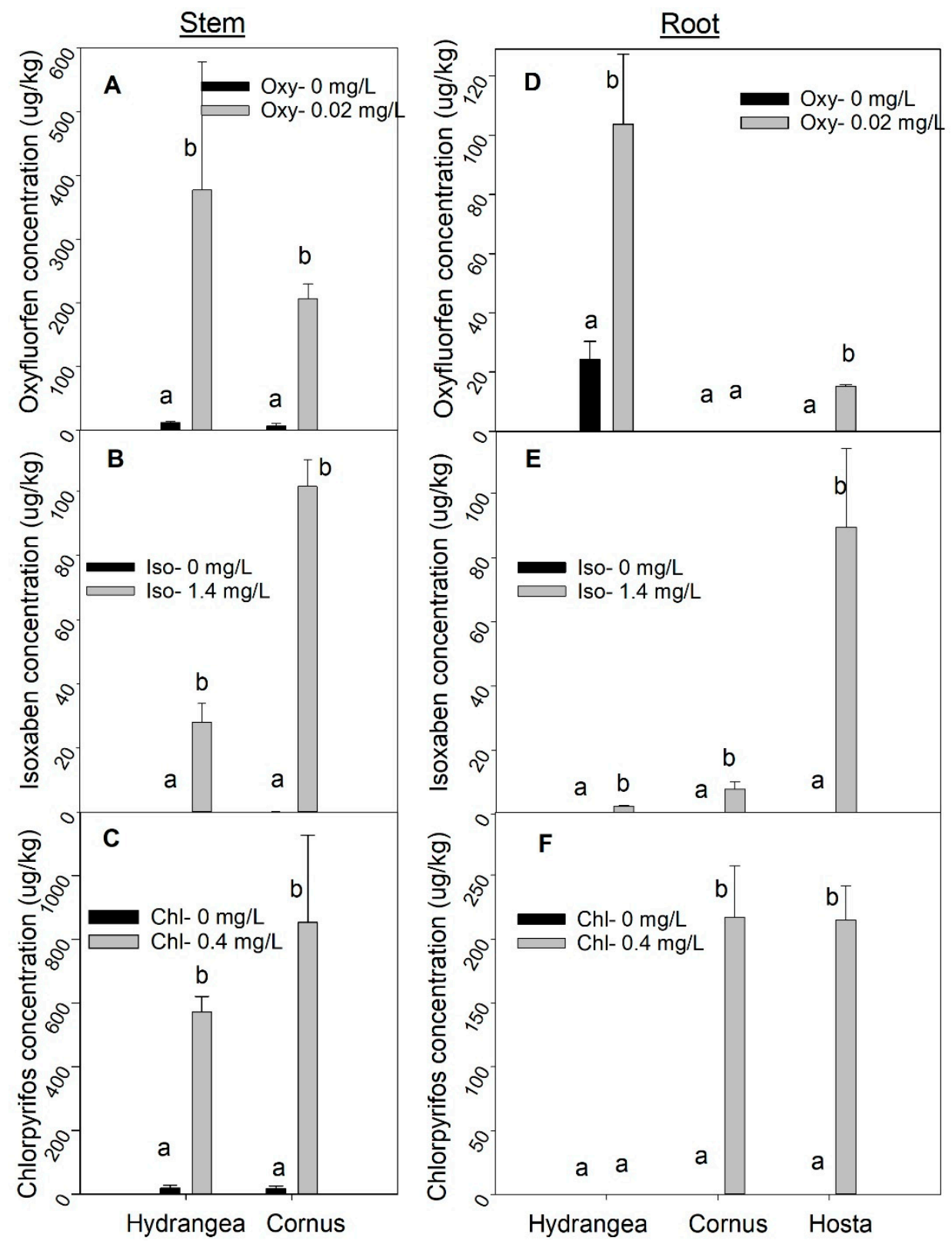

Figure 9. Concentration of oxyfluorfen (A), isoxaben (B), and chlorpyrifos (C) in the stem for Hydrangea paniculata 'Limelight' and Cornus obliqua 'Powell gardens' and concentration of oxyfluorfen (D), isoxaben (E), and chlorpyrifos (F) in root for Hydrangea paniculata 'Limelight', Cornus obliqua 'Powell Gardens', and Hosta 'Gold Standard' plants following irrigation with simulated runoff containing five concentrations of oxyfluorfen (Oxy), isoxaben (Iso), and chlorpyrifos (Chl), applied for three months. Means within a taxon followed by the same letter are not different at $\mathrm{p}<0.05$. Post-hoc mean separation was done using the Fisher least significance difference (LSD) test. Bar graphs for treatment are missing when the residual pesticide concentration is very low (zero or close to zero).

\section{Discussion}

\subsection{Growth and Physiology}

The potential for crop injury from residual pesticides can be a barrier for nursery operators to re-use runoff for irrigation. Additionally, reductions in crop growth from diluted, persistent pesticides can reduce profits by increasing production time or reducing plant quality. Leaves absorb pesticides that are applied to foliage, often producing leaf injury [38]. Visible injury is of concern to nursery 
producers, even if growth is not affected, because aesthetic appearance is important in marketing ornamental plants. Pesticide injury to leaves depends on the dose and type of pesticide used [39]. In this study, oxyfluorfen produced dose-dependent visible injury in all three taxa. Exposure to $0.02 \mathrm{mg} / \mathrm{L} \mathrm{of}$ oxyfluorfen reduced visual leaf rating in Hydrangea, Hosta, and Cornus by 56.7\%, 37.5\%, and 18.4\% when compared to the untreated control, respectively. Isoxaben and chlorpyrifos at the rates we used did not produce any visible injury, and hence irrigation with runoff containing these compounds can be considered relatively safe for use on these taxa. Oxyfluorfen works as a pre-emergent and post-emergence contact herbicide, therefore it is not surprising that it caused the greatest visible injury. When applied to leaves, oxyfluorfen inhibits chlorophyll formation in addition to causing lipid peroxidation and membrane degradation [20]. In contrast, isoxaben is a pre-emergence herbicide that blocks germination [40], and chlorpyrifos is an insecticide. The sensitivity of plants to oxyfluorfen in this study is consistent with observations by nursery growers who have reported crop damage following exposure to oxyfluorfen when runoff water was used as irrigation (personal communication). Oxyfluorfen application also produced leaf injury on rice (Oryza sativa) [41], yellowwood (Cladrastis kentukea) [42], and sunflower [21]. Lactofen, a herbicide with a similar mode of action to oxyfluorfen, also produced leaf injury on soybean leaves [43]. Oxyfluorfen $(0.02 \mathrm{mg} / \mathrm{L})$ reduced the TDB of Hydrangea by $21.5 \%$ and the TBD of Hosta by $43.1 \%$. Because leaves are the site of photosynthesis, visible damge to leaves amy impact photosysnthesis and, hence, productivity. [44]. In our study, leaf injury from oxyfluorfen was observed primarily in Hydrangea and Hosta. For Cornus, leaf injury was only observed at the maximum dose $(0.02 \mathrm{mg} / \mathrm{L})$ of oxyfluorfen. This leaf injury in Hydrangea ultimately led to a reduction in TDB for Hydrangea. Isoxaben and chlorpyrifos did not injure leaves; therefore, healthy growth was seen in plants receiving those pesticides.

Effects of exposure to pesticides in simulated runoff irrigation on photosynthetic parameters largely reflected sensitively as seen in visible injury to leaves. Isoxaben and chlorpyrifos did not affect the SPAD chlorophyll index, but oxyfluorfen reduced chlorophyll index for Hydrangea and Cornus. Oxyfluorfen is a protoporphyrinogen oxidase (PPO) inhibitor, and in the presence of light, this herbicide produces reactive oxygen species that break down chlorophyll and organelle membranes [45]. Chlorophyll fluorescence can be an early indicator of pesticide damage and has been used to predict herbicide damage for various taxa [46,47]. In our study, however, oxyfluorfen or chlorpyrifos did not affect light-adapted chlorophyll fluorescence on any taxa. Although exposure to isoxaben in runoff did not affect the SPAD chlorophyll index, it did slightly reduce the light-adapted fluorescence for Cornus and Hydrangea. In a phytoremediation study by Fernandez et al. (1999), isoxaben also reduced chlorophyll fluorescence in canna, pickerel weed, and iris [14].

Photosynthesis and intercellular carbon dioxide response curves (A/Ci) can be used to determine the photosynthetic capacity of plants [48] and the shape of the A/Ci curve is generally determined by the capacity of rubisco for carboxylation (Vcmax) at lower Ci rates $(<200 \mathrm{ppm})$ and the rate of $\mathrm{RuBP}$ regeneration $(\mathrm{J})$ at higher $\mathrm{Ci}$ rates (>300 ppm) [29,49]. Visual observations of the A/Ci curve indicated oxyfluorfen concentrations of 0.015 and $0.02 \mathrm{mg} / \mathrm{L}$ reduced the carboxylation capacity of RUBISCO and the rate of electron transport for RuBP regeneration for Hydrangea. For Hosta, oxyfluorfen rates of $0.01 \mathrm{mg} / \mathrm{L}$ or higher reduced those parameters. These visual observations were also statistically confirmed by calculating Vcmax and J values. Oxyfluorfen reduced Vcmax and J values both for Hydrangea and Hosta, therefore reduction in rate of photosynthesis in both of those taxa was by the decrease in carboxylation capacity of RUBISCO enzyme (at lower Ci) and reduction in the rate of electron transport for RuBP regeneration (at higher $\mathrm{Ci}$ ). Oxyfluorfen did not limit photosynthetic rates, Vcmax, and J for Cornus at any concentrations. Even though isoxaben is a pre-emergent herbicide, it slightly reduced photosynthesis in Hosta when the levels of isoxaben were $0.7 \mathrm{mg} / \mathrm{L}$ or higher, but unlike oxyfluorfen, reduction in Vcmax and J was not observed. The lack of response in Vcmax and Jmax indicated the reduction in photosynthesis was minimal; therefore, it never translated to a decrease in growth. The decline in photosynthesis by oxyfluorfen corresponded strongly toincreased 
leaf injury. Photosynthetic response to pesticide exposure was more sensitive relative to the TDB response to pesticide exposure.

\subsection{Pesticide Absorption}

Oxyfluorfen was absorbed and retained in leaves for all three taxa, and the absorption increased with increasing dose. Even though oxyfluorfen was retained on the leaves of all three taxa, leaf injury varied. Hydrangea had the maximum leaf injury, followed by Hosta, which is also supported by the fact that Hydrangea had the highest leaf retention of oxyfluorfen followed by Hosta. Taxa vary in their tolerance to oxyfluorfen, which is mainly governed by pesticide absorption, pesticide degradation inside leaves, and the affinity of the target sites (sites inside plants where herbicide binds to produce response) to herbicide [50]. For Cornus to be tolerant, either most of the absorbed oxyfluorfen must have degraded inside the leaves or did not from reach the target site for the mode of action. Isoxaben sensitivity is taxa-specific [51], and a wide range of plants are tolerant to lower concentrations of post applied isoxaben [52]. In the current study, isoxaben absorption and retention in leaves were dose-dependent and similar across taxa. Among the pesticides investigated, isoxaben was least absorbed and retained, which may be because the leaf absorption of isoxaben is very low, and isoxaben is minimally translocated beyond the application point [51,52]. Isoxaben also did not produce visible symptoms or reduce growth. The mode of action for isoxaben is the inhibition of cell wall biosynthesis, which is dose-dependent [40]. Our range of doses for isoxaben may not have been high enough to produce phytotoxicity. In a study by Heim et al. [53], variation in the sensitivity of Agrostis palustris to isoxaben was associated with decreased sensitivity of isoxaben binding sites, which might have also occurred in our study. Fernandez et al. [14] found that isoxaben reduced photosynthesis in three monocot species, while a slight reduction in photosynthesis for monocot-Hosta was also observed in our study. Isoxaben application did not reduce photosynthesis in Hydrangea and Cornus as isoxaben response is taxa-specific [33].

Similar to oxyfluorfen and isoxaben, absorption and retention of chlorpyrifos in leaves was also dose-dependent and increased with increasing dose. Chlorpyrifos may enter inside plant tissue through leaves or roots, and its absorption and retention vary within species [54]. In a study by Fan et al. (2013), chlorpyrifos was absorbed and retained in the leaves of six different leafy vegetables with retention concentration varying within species [55]. In our study, absorption and retention of chlorpyrifos did not affect growth and physiological performance on any of the taxa. In wheat, root application of chlorpyrifos led to the accumulation of chlorpyrifos in root and shoots, but growth was not affected [56]. Wheat and rapeseed also absorbed chlorpyrifos that was mixed in irrigation water, but growth was not affected in either taxon [57]. Chlorpyrifos does not have specific sites of action in plants but may produce phytotoxicity depending on dose, however, the dose of chlorpyrifos that we applied was not enough to produce any morphological or physiological symptoms in the three taxa that we tested.

In our study, the type and concentration of pesticides absorbed and retained in fine roots varied dramatically among the taxa. Isoxaben concentrations in stem and fine roots were lower when compared to chlorpyrifos or oxyfluorfen because isoxaben is less mobile in plants, and up to $99 \%$ of isoxaben applied may be adsorbed by pine bark [51,52]. Application of all three pesticides also resulted in the accumulation of those pesticides in the stem, which may either be through root absorption, translocation from the leaves, or both $[50,51,58]$.

\section{Conclusions}

Phytotoxicity due to pesticide exposure from runoff irrigation depends on the plant type, type of pesticide applied, and concentration of pesticide. In our study, $0.01 \mathrm{mg} / \mathrm{L}$ was the threshold level of oxyfluorfen to produce leaf visual injury in Hydrangea and Hosta, while $0.02 \mathrm{mg} / \mathrm{L}$ of oxyfluorfen was required to induce phytotoxicity in Cornus. Irrigation with simulated runoff containing isoxaben or chlorpyrifos was comparatively safe for all three taxa tested. Isoxaben caused a slight reduction 
in PSII efficiency, but neither isoxaben or chlorpyrifos affected dry weight biomass, photosynthetic biochemistry, or caused visible leaf injury as oxyfluorfen did. This response likely reflects the fact that oxyfluorfen is an herbicide that has post-emergent activity and therefore has the potential to affect sensitive plants following prolonged low-dose exposure. The other pesticides examined in this study are an insecticide (chlorpyrifos) and an herbicide without post-emergent activity (isoxaben), which may be less likely to impact plant growth and physiological function. Among the three taxa, Hydrangea was most sensitive, followed by Hosta, and then by Cornus. Differences among taxa in their sensitivity to oxyfluorfen may also be due in part to differences in plant uptake and translocation. The taxa that were most affected by oxyfluorfen exposure, Hydrangea and Hosta, also had the highest leaf residual concentrations of that compound. Growth impacts of pesticide exposure in irrigation water were also linked to physiological function. Pesticides had larger effects on photosynthesis compared to growth. The results of this study establish the potential of using runoff water containing isoxaben and chlorpyrifos. However, consideration should be made on the concentration of pesticides in runoff and plant taxa irrigated. As with all nursery research, a limitation of the current study is that we only considered three taxa, whereas most commercial nurseries produce dozens, if not hundreds, of different types of plants. We specifically selected taxa that had shown sensitivity to pesticides in similar studies, but it is possible that some taxa may have lower thresholds for pesticide impacts than those studied here. Likewise, in addition to the three pesticides studied, other compounds including mefenoxam, oryzalin, glyphosate, acephate, and bifenthrin may be found in nursery retention ponds [39]. We suggest that researchers conduct similar studies with other commonly used pesticides in a nursery and also determine the pesticide sensitivity of the plants that are different from ours. Their research in combination with ours will provide a stronger base for the adoption of irrigation practice using runoff water.

Author Contributions: Conceptualization, S.P. and B.C.; methodology, S.P.; software, S.P.; validation, S.P., R.T.F. and J.O.; formal analysis, S.P.; investigation, S.P.; resources, R.T.F., J.O. and B.C.; data curation, S.P., and B.C.; writing—original draft preparation, S.P.; writing—review and editing, S.P., J.O., R.T.F. and B.C.; visualization, S.P., R.T.F., and B.C.; supervision, B.C., S.P. and R.T.F.; project administration, S.P. and B.C.; funding acquisition, B.C., R.T.F. and S.P.

Funding: The funding for this work was provided by the U.S. Department of Agriculture Specialty Crop Research Initiative (USDA-SCRI) project Clean WateR3 (Reduce, Reuse, Recycle), PROJECT GREEEN (Generating Research and Extension to meet Economic and Environmental Needs), and the Michigan Department of Agriculture and Rural Development (MDARD) Horticulture Fund.

Acknowledgments: We thank Dana Ellision, Becky Pobst, Alex Love, Damon Abdi, and Dan Kort for assisting with the experimental setup, plant harvesting, and data collection.

Conflicts of Interest: The authors declare no conflicts of interest.

\section{References}

1. United States Department of Agriculture National Agricultural Statistics Service. Census of Horticultural Specialties (2014); 2012 Census Agriculture: Washington, DC, USA, 2015; AC-12-SS-3.

2. Warsaw, A.L.; Fernandez, R.T.; Cregg, B.M.; Andresen, J.A. Container-grown ornamental plant growth and water runoff nutrient content and volume under four irrigation treatments. HortScience 2009, 44, 1573-1580.

3. Danelon, M.; Kachenko, A.; McDonald, J.; Rolfe, C.; Yiasoumi, B. Nursery industry water management best practice guidelines 2010. In Nurs. Gard. Ind. Aust. 2010; Kachenko, A., Ed.; Nursery \& Garden Industry Australia: New South Wales, Australia, 2010.

4. Mathers, H.M.; Yeager, T.H.; Case, L.T. Improving irrigation water use in container nurseries. HortTechnology 2005, 15, 8-12. [CrossRef]

5. Warsaw, A.L.; Thomas Fernandez, R.; Kort, D.R.; Cregg, B.M.; Rowe, B.; Vandervoort, C. Remediation of metalaxyl, trifluralin, and nitrate from nursery runoff using container-grown woody ornamentals and phytoremediation areas. Ecol. Eng. 2012, 47, 254-263. [CrossRef] 
6. Lao, W.J.; Arye, G.; Ernst, F.; Xu, Y.P.; Bondarenko, S.; Haver, D.; Kabashima, J.; Gan, J. Reduction of Pyrethroid Runoff from a Commercial Nursery; ACS Symposium Series; ACS Publication: Washington, DC, USA, 2008; Volume 991, pp. 428-446.

7. Keese, R.J.; Camper, N.D.; Whitwell, T.; Riley, M.B.; Wilson, P.C. Herbicide Runoff from Ornamental Container Nurseries. J. Environ. Qual. 1994, 23, 320-324. [CrossRef]

8. Brown, K. Water scarcity: Forecasting the future with spotty data. Science 2002, 297, 926-927. [CrossRef]

9. Schmitz, C.; Lotze-campen, H.; Gerten, D.; Dietrich, J.P.; Bodirsky, B.; Biewald, A.; Popp, A. Blue water scarcity and the economic impacts of future agricultural trade and demand. Water Resour. Res. 2013, 49, 3601-3617. [CrossRef]

10. Capturing and Recycling Irrigation Runoff as a Pollution Prevention Measure. Available online: http://pods. dasnr.okstate.edu/docushare/dsweb/Get/Document-7408/BAE-1518web.pdf (accessed on 8 November 2019).

11. Bhandary, R.M.; Whitwell, T.; Briggs, J. Growth of Containerized Landscape Plants is Influenced by Herbicides Residues in Irrigation Water. Weed Technol. 1997, 11, 793-797. [CrossRef]

12. Briggs, J.A.; Whitwell, T.; Riley, M.B. Effect of delayed irrigation on isoxaben and oryzalin runoff from a container nursery. Weed Sci. 2003, 51, 463-470. [CrossRef]

13. Briggs, J.A.; Riley, M.B.; Whitwell, T. Quantification and remediation of pesticides in runoff water from containerized plant production. J. Environ. Qual. 1998, 27, 814-820. [CrossRef]

14. Fernandez, R.T.; Whitwell, T.; Riley, M.B.; Bernard, C.R. Evaluating Semiaquatic Herbaceous Perennials for Use in Herbicide Phytoremediation. J. Am. Soc. Hortic. Sci. 1999, 124, 539-544. [CrossRef]

15. Neal, J.C.; Senesac, A.F. Preemergent Herbicide Safety in Container-grown Ornamental Grasses. HortScience 1991, 26, 157-159. [CrossRef]

16. Parween, T.; Jan, S.; Fatma, T. Alteration in nitrogen metabolism and plant growth during different developmental stages of green gram (Vigna radiata L.) in response to chlorpyrifos. Acta Physiol. Plant. 2011, 33, 2321-2328. [CrossRef]

17. Parween, T.; Jan, S.; Mahmooduzzafar, S.; Fatma, T. Evaluation of oxidative stress in Vigna radiata L. in response to chlorpyrifos. Int. J. Environ. Sci. Technol. 2012, 9, 605-612. [CrossRef]

18. Prasad, S.M.; Singh, A.; Singh, P. Physiological, biochemical and growth responses of Azolla pinnata to chlorpyrifos and cypermethrin pesticides exposure: A comparative study. Chem. Ecol. 2015, 31, 285-298. [CrossRef]

19. Dow AgroSciences Specimen Label: Goal 2XL. Available online: http://www.cdms.net/ldat/ld5S1007.pdf (accessed on 8 November 2019).

20. Lee, H.J.; Duke, S.O. Protoporphyrinogen IX-Oxidizing Activities Involved in the Mode of Action of Peroxidizing Herbicides. J. Agric. Food Chem. 1994, 42, 2610-2618. [CrossRef]

21. Jursik, M.; Andr, J.; Holec, J.; Soukup, J. Efficacy and selectivity of post-emergent application of flumioxazin and oxyfluorfen in sunflower. Plant Soil Environ. 2011, 57, 532-539. [CrossRef]

22. Vea, E.; Palmer, C. IR-4 Ornamental Horticulture Program Oxyfluorfen Crop Safety. 2009. Available online: http://ir4.rutgers.edu/Ornamental/SummaryReports/OxyfluorfenDataSummary2009.pdf (accessed on 8 November 2019).

23. Horowitz, M.; Elmore, C.; Boquist, D. Directed application of Goal (Oxyfluorfen) to container grown Euonymus, to minimize phytotoxicity and leaching. J. Environ. Hortic. 1989, 7, 17-21.

24. Krugh, B.W.; Miles, D. Monitoring the effects of five "nonherbicidal" pesticide chemicals on terrestrial plants using chlorophyll fluorescence. Environ. Toxicol. Chem. 1996, 15, 495-500. [CrossRef]

25. Spiers, J.D.; Davies, T.; He, C.; Heinz, K.M.; Bogran, C.E.; Starman, T.W. Do insecticide affect plant growth and development? Greenh. Grow. 2008, 2, 1-3.

26. Vinet, L.; Zhedanov, A. Crop Stress and Its Management: Perspectives and Strategies; Venkateswarlu, B., Shanker, A.K., Shanker, C., Maheswari, M., Eds.; Springer: Dordrecht, The Netherlands, 2012; ISBN 978-94-007-2219-4.

27. Parween, T.; Jan, S.; Mahmooduzzafar, S.; Fatma, T. Assessing the impact of chlorpyrifos on growth, photosynthetic pigments and yield in Vigna radiata L. at different phenological stages. Afr. J. Agric. Res. 2011, $6,4432-4440$.

28. Veeraswamy, J.; Padmavathi, T.; Venkateswarlu, K. Effect of selected insecticides on plant growth and mycorrhizal development in sorghum. Agric. Ecosyst. Environ. 1993, 43, 337-343. [CrossRef] 
29. Sharkey, T.D.; Bernacchi, C.J.; Farquhar, G.D.; Singsaas, E.L. Fitting photosynthetic carbon dioxide response curves for C3 leaves. Plant Cell Environ. 2007, 30, 1035-1040. [CrossRef] [PubMed]

30. Sharkey, T.D. What gas exchange data can tell us about photosynthesis. Plant Cell Environ. 2016, 39, 1161-1163. [CrossRef] [PubMed]

31. Lal, S.; Saxena, D.M.; Lal, R. Effects of DDT, fenitrothion and chlorpyrifos on growth, photosynthesis and nitrogen fixation in Anabaena (Arm 310) and Aulosira fertilissima. Agric. Ecosyst. Environ. 1987, 19, 197-209. [CrossRef]

32. Salihu, S.; Derr, J.F.; Hatzios, K.K. Differential Response of Ajuga (Ajuga reptans), Wintercreeper (Euonymus fortunei), and Dwarf Burning Bush (Euonymus alatus 'Compacta') to Root-and Shoot-Applied Isoxaben. Weed Technol. 1999, 13, 685-690. [CrossRef]

33. Willoughby, I.; Clay, D.; Dixon, F. The effect of pre-emergent herbicides on germination and early growth of broadleaved species used for direct seeding. Forestry 2003, 76, 83-94. [CrossRef]

34. Gonzalez, M.P.; Karlik, J. Evaluation of Herbicides for Phytotoxicity to Rose Plants and Efficacy. J. Environ. Hortic. 1999, 17, 164.

35. Riley, M.B.; Keese, R.J.; Camper, N.D.; Whitwell, T.; Chris, P.; Riley, M.B.; Keese, R.J.; Camper, N.D.; Whitwell, T.E.D.; Wilson, P.C. Pendimethalin and Oxyfluorfen Residues in Pond Water and Sediment from Container. Weed Technol. 1994, 8, 299-303. [CrossRef]

36. Mangiafico, S.S.; Newman, J.; Merhaut, D.J.; Gan, J.; Faber, B.; Wu, L. Nutrients and Pesticides in Stormwater runoff and soil water in production nurseries and citrus and avocado groves in California. HortTechnology 2009, 19, 360-367. [CrossRef]

37. Raina, R. Chemical Analysis of Pesticides Using GC/MS, GC/MS/MS, and LC/MS/MS. In Pesticides-Strategies for Pesticides Analysis; Stoytcheva, M., Ed.; InTech: Rijeka, Croatia, 2011.

38. Stevens, P.J.G.; Baker, E.A. Factors affecting the foliar absorption and redistribution of pesticides. 1. Properties of leaf surfaces and their interactions with spray droplets. Pestic. Sci. 1987, 19, 265-281. [CrossRef]

39. Poudyal, S.; Cregg, B.M. Workshop: Irrigating Nursery Crops with Recycled Run-off: A Review of the Potential Impact of Pesticides on Plant Growth and Physiology. HortTechnology. 2019. Available online: https://doi.org/10.21273/HORTTECH04302-19 (accessed on 8 November 2019).

40. Heim, D.R.; Skomp, J.R.; Tschabold, E.E.; Larrinua, I.M. Isoxaben Inhibits the Synthesis of Acid Insoluble Cell Wall Materials in Arabidopsis thaliana. Plant Physiol. 1990, 93, 695-700. [CrossRef] [PubMed]

41. Priya, S.R.; Chinnusamy, C.; Arthanar, M.P.; Janaki, P. Carryover effect and plant injury from oxyfluorfen herbicide applied in transplanted rice. Int. J. Chem. Stud. 2017, 5, 535-539.

42. Mathers, H. Herbicide Injury. Michigan State Univ. Coll. Agric. Nat. Resour. Available online: https://www.canr.msu.edu/uploads/files/623\%20Nursery\%20grower\%20checklist $\%$ 20TOM\%20herbicide\%20injury.pdf (accessed on 8 November 2019).

43. Wichert, R.A.; Talbert, R.E. Soybean [Glycine max (L.)] Response to Lactofen. Weed Sci. 1993, 41, $23-27$. [CrossRef]

44. Kirschbaum, M.U.F. Does enhanced photosynthesis enhance growth? Lessons learned from $\mathrm{CO}_{2}$ enrichment studies. Plant Physiol. 2011, 155, 117-124. [CrossRef] [PubMed]

45. Sherwani, S.I.; Arif, I.A.; Khan, H.A. Modes of Action of Different Classes of Herbicides. In Herbicides, Physiology of Action, and Safety; Price, A., Kelton, J., Sarunaite, L., Eds.; InTech: Rijeka, Croatia, 2015; pp. 165-186. [CrossRef]

46. Wang, P.; Li, H.; Jia, W.; Chen, Y.; Gerhards, R. A fluorescence sensor capable of real-time herbicide effect monitoring in greenhouses and the field. Sensors 2018, 18, 3771. [CrossRef] [PubMed]

47. Barbosa Silva, F.; Carlos Costa, A.; Rodrigo Pereira Alves, R.; A parecida Megguer, C. Chlorophyll Fluorescence as an Indicator of Cellular Damage by Glyphosate Herbicide in Raphanus sativus L. Plants. Am. J. Plant Sci. 2014, 5, 2509-2519. [CrossRef]

48. Singh, S.K.; Badgujar, G.; Reddy, V.R.; Fleisher, D.H.; Bunce, J.A. Carbon dioxide diffusion across stomata and mesophyll and photo-biochemical processes as affected by growth $\mathrm{CO}_{2}$ and phosphorus nutrition in cotton. J. Plant Physiol. 2013, 170, 801-813. [CrossRef]

49. Dinh, T.H.; Watanabe, K.; Takaragawa, H.; Nakabaru, M.; Kawamitsu, Y. Photosynthetic response and nitrogen use efficiency of sugarcane under drought stress conditions with different nitrogen application levels. Plant Prod. Sci. 2017, 20, 412-422. [CrossRef] 
50. Chun, J.C.; Lee, H.J.; Lim, S.J.; Kim, S.E.; Guh, J.O. Comparative absorption, translocation, and metabolism of foliar-applied oxyfluorfen in wheat and barley. Pestic. Biochem. Physiol. 2001, 70, 118-125. [CrossRef]

51. Schneegurt, M.A.; Roberts, J.L.; Bjelk, L.A.; Gerwick, B.C. Postemergence Activity of Isoxaben. Weed Technol. 1994, 8, 183-189. [CrossRef]

52. Wehtje, G.; Gilliam, C.H.; Miller, M.E.; Altland, J.E. Foliar vs. Root Sensitivity of Hairy Bittercress (Cardamine hirsuta) to Isoxaben. Weed Technol. 2006, 20, 326-333. [CrossRef]

53. Heim, D.R.; Bjelk, L.A.; James, J.; Schneegurt, M.A.; Larrinua, I.M. Mechanism of isoxaben tolerance in Agrostis palustris var. Penncross. J. Exp. Bot. 1993, 44, 1185-1189. [CrossRef]

54. Lu, M.-X.; Jiang, W.W.; Wang, J.-L.; Jian, Q.; Shen, Y.; Liu, X.-J.; Yu, X.-Y. Persistence and Dissipation of Chlorpyrifos in Brassica Chinensis, Lettuce, Celery, Asparagus Lettuce, Eggplant, and Pepper in a Greenhouse. PLoS ONE 2014, 9, e100556. [CrossRef] [PubMed]

55. Fan, S.; Zhang, F.; Deng, K.; Yu, C.; Liu, S.; Zhao, P.; Pan, C. Spinach or amaranth contains highest residue of metalaxyl, fluazifop-p-butyl, chlorpyrifos, and lambda-cyhalothrin on six leaf vegetables upon open field application. J. Agric. Food Chem. 2013, 61, 2039-2044. [CrossRef] [PubMed]

56. Copaja, S.V.; Vergara, R.; Bravo, H.R. Bioavailability of Chlorpyrifos in Wheat Plants (Triticum aestivum). Agric. Sci. 2014, 5, 660-667.

57. Wang, L.; Jiang, X.; Yan, D.; Wu, J.; Bian, Y.; Wang, F. Behavior and fate of chlorpyrifos introduced into soil-crop systems by irrigation. Chemosphere 2007, 66, 391-396. [CrossRef] [PubMed]

58. Duke, S. Overview of Herbicide Mechanisms of Action. Environ. Health Perspect. 1990, 87, 263-271. [CrossRef]

(C) 2019 by the authors. Licensee MDPI, Basel, Switzerland. This article is an open access article distributed under the terms and conditions of the Creative Commons Attribution (CC BY) license (http://creativecommons.org/licenses/by/4.0/). 